\title{
Article \\ Pedagogical Ecology for an Alternative Sustainability: With Insights from Francis of Assisi and Contemporary Life Sciences
}

\author{
Giuseppe Buffon ${ }^{1, *}$ and Ivan Colagè $\grave{2}^{2,3}$ \\ 1 Faculty of Theology, Pontifical University Antonianum, 00185 Rome, Italy \\ 2 Faculty of Philosophy, Pontifical University Antonianum, 00185 Rome, Italy; i.colage@antonianum.eu or \\ i.colage@pusc.it \\ 3 DISF Research Centre, Pontifical University of the Holy Cross, 00186 Rome, Italy \\ * Correspondence: g.buffon@antonianum.eu
}

check for updates

Citation: Buffon, G.; Colagè, I.

Pedagogical Ecology for an Alternative Sustainability: With Insights from Francis of Assisi and Contemporary Life Sciences.

Sustainability 2022, 14, 1395. https:// doi.org/10.3390/su14031395

Academic Editors: Lluis Oviedo,

Sara Lumbreras and

Hans-Ferdinand Angel

Received: 31 December 2021

Accepted: 24 January 2022

Published: 26 January 2022

Publisher's Note: MDPI stays neutral with regard to jurisdictional claims in published maps and institutional affiliations.

Copyright: (C) 2022 by the authors. Licensee MDPI, Basel, Switzerland. This article is an open access article distributed under the terms and conditions of the Creative Commons Attribution (CC BY) license (https:// creativecommons.org/licenses/by/ $4.0 /)$.

\begin{abstract}
Sustainability is a widely discussed issue nowadays. The "human factor" appears to be the key to a suitable theory of sustainable development and, even more, to understanding the real scope of the issue at stake. We begin by highlighting that the issue of sustainability and the related ecological crisis ultimately stem from the fundamental view of the human-environment relationships. We tackle such a fundamental view from two apparently distant but converging perspectives: the one of Francis of Assisi (the patron saint of ecologists) and the one of contemporary advancements in evolutionary biology known as the "extended evolutionary theory" (EES). This will allow us to highlight how current life sciences ground a strong form of organism-environment complementarity-a core point for any allegedly comprehensive approach to sustainability and ecology. After that, we focus on recent developments in cultural evolution studies that see culture both as the driving force of (recent) human evolution and as the general context where the human-environment relationships take place and develop. Therefore, we argue that the environment exerts a powerful pedagogical influence on the human being and on humanity as a whole. We conclude by proposing a pedagogical criterion for ecology and sustainable development, according to which the modifications caused by the human being to the environment must be assessed (also) for their pedagogical import.
\end{abstract}

Keywords: cultural evolution studies; ecological inheritance; environment; extended evolutionary synthesis; Francis of Assisi; niche construction; pedagogy; phenotypic plasticity

\section{Introduction}

The issue of sustainability is at the centre of extensive interdisciplinary debate nowadays. Many technical issues are involved, from physical sciences to life and cognitive sciences, from engineering to economy and sociology. Besides those technical issues, the awareness that the "human factor" - i.e., the personal and social level of daily and longterm decisions, actions and behaviour-plays a key role in sustainability is mounting up. The 1967 Science paper [1] by historian Lynn White (1907-1987) — a professor of medieval history at Princeton, Stanford and Los Angeles - can be considered as an important turning point in the ecological debate. Of course, it is neither the first document relevant to the issue nor the most important in view of a technical appraisal of ecological and sustainabilityrelated issues; however, White's paper raises two points that are key for what follows in this article.

First, it stressed that "the historical roots of our ecological crisis" - this is the title of the paper-should be found in a fundamental human attitude towards nature or, more generally, in a specific conception of the nature-humanity relationship. According to White, that attitude sees this relationship essentially in terms of the human being's "transcendence of, and rightful mastery over, nature" [1] (p. 1206). The roots of this view are traced back to the developments of Wester Christianity during the Middle Ages. Interestingly, 
these developments are also considered as the condition of possibility for the birth and rapid growth of modern science and technology. Starting from these claims, White states that being the fruits of that view - the ecological crisis on the one hand and science and technology on the other-the solution to the ecological crisis cannot come from science and technology themselves. On the contrary, White stresses, "Since the roots of our trouble are so largely religious, the remedy must also be essentially religious, whether we call it that or not" [1] (p. 1207). This casts, in our view, strong emphasis on the relevance of the human factor in sustainability and ecology - and also confers further relevance to the claim that human features such as beliefs and values are "critical factors that can determine the success or failure of any plan to improve sustainable models, policies or programs" [2] (p. 2).

The second point we take from White's work is the acknowledgement of Saint Francis of Assisi as the most notable-actually, the only one in White's opinion-exception to the generalised Western view on the nature-humanity relationships mentioned above. St. Francis-whom White proposed as the patron saint for ecologists 12 years before Pope John Paul II declared him such officially [3] - is praised as the one who "tried to depose man from his monarchy over creation and set up a democracy of all God's creatures" [1] (p. 1206).

We build upon these two points along a precise direction: the one emphasising the strong pedagogical link between the environment and humanity - thus elaborating on the notion of a "pedagogical ecology"-i.e., the idea that the environment can play and has actually played along human evolutionary history, a key role in shaping not just human lifestyle but also the very human biological, cognitive, and cultural constitution. This will bring us to propose a "pedagogical criterion for ecology", according to which the impact of human interventions in and on the environment should also be assessed for its specifically pedagogical import.

To this aim, we will first focus on key aspects of the thought of Francis of Assisi, stressing how it actually promotes a model of sustainable market and consumption. This is based on the idea of "necessitas" — the idea that any creature, human beings included, can take from the environment only what is really indispensable, necessary for its life. We will also stress the pedagogical role Francis attributes to the creatures, which can assist and support the human being in what the patron saint for ecologists maintains-as it were-to be the highest human duty: to praise the Lord ("Laudato si' mi Signore"). After that, we will show how, in the thought of Francis of Assisi, in spite of the core emphasis on "necessitas", there is an important space for superfluous things, for creativity, and for a "playful attitude" towards nature. This is an important point, especially because, nowadays, more than in the past, the issue of sustainability cannot be conceived without the issue of development, growth, and progress - as the phrasing "sustainable development", at the heart of many ecological discourses, highlights significantly.

Secondly, we will focus on the general issue of the organism-environment relationships, as seen in contemporary life sciences, and on the specific relation the human being has always entertained with its environment. This will allow us to deepen the issue raised by White's paper through the lenses of contemporary advancements in the life sciences, with a particular focus on evolutionary biology and cultural evolution studies. We will see how the organism-environment relationships are those of mutual, reciprocal change, and modification. The organisms constantly modify the environment in which they live, directly or indirectly. The environment deeply changes and shapes the organisms dwelling in it. We will also see how the environment affects the organisms in two fundamental ways: "downstream" (essentially by means of natural selection) and "upstream" (influencing organisms' phenotypic development on the levels of morphology, anatomy and physiology, as well as of behaviour and cognition). From this, we will address the human-specific relation to the environment, which is deeply transformative in character. Culture, here, will come to play a key role, being the "place" where the organism-environment relationships occur and develop in the case of the human being. Here, two points will acquire 
specific relevance. In the first place, we will see that, in the course of Homo evolution, the relationship of human populations with their environment cannot be entirely understood in terms of the "necessitas" emphasised by Francis of Assisi: as a matter of fact, a trend to improve life conditions, style, and quality beyond pure needs can be inferred from the data available nowadays. In the second place, however, we will stress that - though not be reducible to pure "necessitas" - the human-environment relationship can neither be understood in terms of a trend aimed at increasing mere exploitation and consumption of natural resources. Thus, we will propose that one interesting way to characterize the human-environment relationship is that of claiming that the human being changes the environment with the aim of shaping itself. This would represent a fundamental shift in perspective. The relationship with the environment may be no longer understood (only) in terms of consumption vs. saving, exploitation vs. decrease, but from the viewpoint of the overall- "integral", indeed-impact that human-driven changes in the environment cause on the human being itself as part and parcel of the environment. It is from this perspective that the pedagogical role of the environment on humanity stems and the pedagogical criterion for ecology emerges.

\section{The Contemporary Relevance of Francis of Assisi's Model}

\subsection{Mother Earth, Our Common Home. For Human and Economic Sustainability}

According to Francis of Assisi, the natural environment represents a model of social and anthropological sustainability alternative to the "consumer society" that was already emerging with the "pre-capitalism" of the Communes in the Western Middle Ages. Proposing the image of the Earth not just as a sister but as a mother that sustains and governs humanity, Francis of Assisi promotes political and economic sustainability coherent with natural and eco-systemic parameters. The religious, theological basis for this is the conviction that nature is a mirror of God's Incarnation so that humanity is called to collaborate with Creation and not just to rule despotically over it [4] (p. 195). In the 13th centurycharacterized by the attitude to dominate nature that would produce the pre-industrial cities hoarding the resources from rural areas and the Signoria system of the late Middle Ages-Francis of Assisi chants the maternal character of the Earth, which sustains and governs without dominion, and avoids any reference to the "potestas", i.e., the sovereign authority of the lords based on economic power. Thus, he criticizes, ante litteram, the very idea of the Homo oeconomicus [5]. The feminine and maternal features, and not the masculine authoritarian and hegemonic ones, ground a brotherhood sustainable exactly because it is rooted in a mother-like political love and charity. Francis of Assisi even avoids attributing to himself the role of a "father" for his followers, defining himself "sicut mater" (like a mother) [6,7] (vol. 1, p. 122).

In The Canticle of the Creatures (or Canticle of the Sun), where the Earth is indeed declared "mother", only the creatures can make the human being sustainable in spite of its uselessness - useless to the point of being unable and even unworthy to name God: "nullu homo éne dignu te mentovare" ("no human is worthy to mention Your name"). According to the author of the Canticle, the human being is unable to stay in touch with its own origin, unsuitable to decipher the sense of its very existence, unequipped to weave relationships with other human beings, the companions of its life-journey. For this reason, humanity does not realize a sustainable social coexistence nor a full human universal brotherhood that ensures the dignity of each and every individual. The core message of Francis' Canticle is that only the choir of all creatures can offer the human being the chance for social reconciliation and, even deeper, for coming to terms with "Sister Bodily Dead", which makes human existence so problematic [8]. It is here that Francis' conviction of the maieutic, pedagogical role of the creatures towards the human being becomes evident. Indeed, the strophes of the Canticle about the solution of the social conflicts, thanks to forgiving, as well as the verses on the death acknowledged as a sister, appear at the end of the poetry-i.e., only after the creatures have exerted their performative transformative power upon the human being, from the social to the spiritual dimension. Additionally, in this case, the 
religious and theological implication is that the creatures play a role of Christological mediation for the human being as they are part of the "cosmic Christ", the firstborn of every creature.

The performative and, hence, pedagogical role assigned to creatures by Francis of Assisi can be inferred from the function of the grammatical connectives, e.g., "cum" (with) "Laudato sie, mi Signore, cum tucte le Tue creature": Praised be You, my Lord, with all Your creatures—and "per" (through) —“Laudato si', mi Signore per frate Vento ... per sor'Aqua ... per frate Focu: Praised be You, my Lord, through Brother Wind ... through Sister Water ... through Brother Fire- that are largely used in the Canticle. The two connectives should be given an instrumental meaning: "by means of". Such a mediating role of creatures is stressed by other passages of the Canticle, such as the one addressed to Brother Fire, "through whom You light the night" or the one about Brother Wind, "through which You give sustenance to Your creatures".

The biographers of St. Francis were particularly attentive to the model of social sustainability offered by the creatures, attention sharpened by the concrete problems for the alimentary and economic sustenance of the early Franciscan brotherhood that, after Francis' death, enrolled many new members and took on a number of ecclesial duties. These concrete problems had to be tackled without betraying the ideal of nature relieving human unsustainability expressed in Francis' Canticle. In this context, the raw natural products served as a source of supply alternative to the socio-economic and market set-up of the time, from which Franciscans intended to dissent. It is worth briefly mentioning that such dissent, and the consequent emphasis on poverty, was also embraced by other groups at the time (e.g., Waldensians, or Bogomils and Cathars), but the Franciscan view was distant from the dichotomic, "Manichean" attitude of these groups and was grounded on a different conception of nature and humanity and, hence, of poverty itself and of the value of goods.

Indeed, moreover, creatures are taken as examples of virtuous (and sustainable) behaviour. In The Assisi Compilation (Compilatio Assisiensis), Francis admires the lark for the way in which it gets food: it is satisfied with what it simply finds along its way, rummaging in the manure as well [7] (vol. 2, p. 130). Analogously, Francis appreciates all the birds that can live with what nature offers them spontaneously. He is also touched by domesticated animals, especially the most docile ones such as sheep, cows and donkeys, which are content with the food they receive daily-just like the Friars Minor, according to The Earlier Rule, are expected to live either by the work they can do or by begging [7] (vol. 1, p. 68).

The animal kingdom, where nourishment is gathered from the surroundings without disturbing the eco-systemic equilibrium, grounds the economic routine of the early Franciscan community, opposing the accumulation of goods as something subverting the social equilibrium and not just the environmental one. Francis' rules for the friars establish not only that the goods must not be owned (renouncing the property right that can allow accumulation of goods), but that they can be used exclusively as far as they are strictly necessary [7] (vol. 1, p. 70). According to The Later Rule, the goods have the only aim of satisfying the physical needs of the human species, ensuring subsistence and good health [7] (vol. 1, p. 102). The value of the goods cannot, thus, depend only on the rules of the market but is rooted in their use-value, i.e., in their value at the service of the real human needs. Goods' use-value, established by their relevance for human necessities, undermines the exchange-value and its monetary quantification, emphasising the goods' natural and creatural value [9]. Goods' value, thus, depends also on their availability within the ecosystem that sustains the human being and satisfies its needs.

\subsection{Against a Consumerism-Based Market Logic}

The Franciscan proposal is not only the ethics of solidarity but constitutes a real alternative to the economic system based on the law of supply and demand. Restricting the use of goods to the sole real necessity implies evaluating them according to a natural/creatural criterion and not just pricing them in market logic. Francis of Assisi identifies the limits to 
the use of goods with their actual availability in the ecosystem. This does not imply that the human being should not increase the effectiveness of natural resources by means of his work and thanks to the use of technology. However, human craft cannot disrupt the equilibrium of nature, and even more so if this is done for consumerism.

Francis' model of a sustainable economy, based on the idea of "necessitas", is rendered by his biographers in eloquent narratives. Particularly interesting from this viewpoint is the "Lifes" of Saint Francis, written by his first biographer, Thomas of Celano, who represents the original conception of poverty by the saint, as expressed in both The Earlier Rule and The Later Rule and as rooted in the view of nature and humanity characterising the Canticle of the Creatures. Accordingly, in The Life of Saint Francis by Thomas of Celano, episodes in which St. Francis liberates animals caught to be sold at the market are conceived to decry a socio-economic system that alters the natural equilibrium instead of taking the latter as a model. "Once while he was staying near the town of Greccio, a certain brother brought him a live rabbit caught in a trap. Seeing it, the most blessed man was moved with tenderness. 'Brother rabbit', he said, 'come to me. Why did you let yourself get caught?' As soon as the brother holding it let go, the rabbit, without any prompting, took shelter with the holy man, as in a most secure place, resting in his bosom. After it had rested there for a little while, the holy father, caressing it with motherly affection, let it go so that now free it would return to the woods. As often as it was put on the ground, it rushed back to the holy man's lap, so he told the brothers to carry it away to the nearby forest." [7] (vol. 1, p. 235). This and other episodes are meant to emphasise Francis' desire that the growing Franciscan community itself relinquished the market logic and the consequent attitude to overuse natural resources. The point is also emphasised in the well-known text by Thomas of Celano on Francis preaching to the birds: "My brother birds, you should greatly praise your Creator, and love Him always. He gave you feathers to wear, wings to fly, and whatever you need. God made you noble among His creatures and gave you a home in the purity of the air, so that, though you neither sow nor reap. He nevertheless protects and governs you without your least care." [7] (vol. 1, p. 234). Here, the freedom of the birds from any market logic - even as far as basic subsistence is concerned-is praised and admired and also presented as a model for the Franciscan community on the basis of the Gospel passage in which Jesus proposed the birds as a model as well (Mattew 6:26).

Several scholars have analysed the passages in which St. Francis frees animals destined to the market [10-13]. Another two episodes, again from The Life of Saint Francis by Thomas of Celano, are worth mentioning here. The first one:

"There was one little sheep walking humbly and grazing calmly among these many goats. When blessed Francis saw it, he stopped in his tracks, and touched with sorrow in his heart, he groaned loudly and said to the brother accompanying him: 'Do you see that sheep walking so meekly among those goats? I tell you, in the same way, our Lord Jesus Christ, meek and humble, walked among the Pharisees and chief priests. So I ask you, my son, in your love for Him to share my compassion for this little sheep. After we have paid for it, let us lead this little one from the midst of these goats'. Brother Paul was struck by his sorrow and also began to feel that sorrow himself. They had nothing except the cheap tunics they wore and they were concerned about how to pay for the sheep, when suddenly a travelling merchant arrived and offered to pay for what they wanted" [7] (vol. 1, p. 248-9).

And also:

"On another occasion, he was travelling through the Marches, and the same brother was gladly accompanying him when he came across a man on his way to market. The man was carrying over his shoulder two little lambs bound and ready for sale. When blessed Francis heard the bleating lambs, his innermost heart was touched and, drawing near, he touched them as a mother does with a crying child, showing his compassion. 'Why are you torturing my brother lambs', he said to the man, 'binding and hanging them this way?' 'I am carrying them to market to sell them since I need the money', he replied. The holy man asked: 'What will happen to them?' 'Those who buy them will kill them and eat them', he responded. At that, the holy man said: 'No, this must not happen! Here, take my cloak as 
payment and give me the lambs'. The man readily gave him the little lambs and took the cloak since it was much more valuable" [7] (vol. 1, p. 249).

This latter passage contains an explicit criticism of the market logic, evident even from the fact that the cloak "was much more valuable" than the goods bought with it. The meaning of the first one can be grasped better if one takes into account the parallel between the little sheep and Jesus Christ, who was sold to the Sanhedrin.

In both episodes, the victims have been saved by means of money, which thus is transformed from being the end-goal of the business to being the means through which the natural world can find its intrinsic value again and not the monetary value fixed by the market exchange. It is interesting that in the first episode, a merchant entered Francis novel logic, which is intended to correspond to the logic of nature itself. In both episodes, moreover, Francis is moved by compassion, which is opposed to the economic interest. And such compassionate feelings are triggered by the consideration of the suffering of the body, which the human being shares with the animal kingdom. Contemporary defence of animal rights is indeed based on the idea that animals have sentience to bodily harm and that such sentience should be considered by legal systems [14].

Francis of Assisi's fondness for farmers' culture, represented by livestock and for wild animals associated with the rural world, as presented by Thomas of Celano, can be interpreted as the preference for the countryside over the urban environment. The cities-the Communes in the 12th and 13th centuries-absorbed the great part of the resources, both in terms of goods and of workers, from the countryside. Thus, the cities were regarded as something subjugating the rural environment and lifestyle; the poverty and social marginalization of the countryside were perceived akin to the ideal of poverty and humbleness assumed by the early Franciscan community.

\subsection{Sustainability beyond Necessity}

The poverty and docility represented by the animal world could not be understood in purely naturalistic terms, according to Thomas of Celano. Nature in the raw could not be equivalent to divine perfection nor be radically contraposed to human ethical decay. Thus, The Second Life of St. Francis by Thomas of Celano presents episodes in which Francis punishes animals for their violation of the "cosmic fraternity" depicted in The Canticle of the Creatures. The stories of Francis with the animals are rooted in a conception of nature as created and saved, Edenic and eschatological, i.e., the nature of the Garden, both at the beginning/origin and at the end/fulfilment of history. The violence of hunting animals could not be the object of condemnation; otherwise, carnivores would not have survived. In the Biblical accounts of Creation, indeed, God sets the right of every creature to consume all that corresponds to one's needs ("necessitas"), but no more. Consequently, any behaviour exceeding the limits of the real needs is against justice and cannot be accepted. For example, in The Remembrance of the Desire of a Soul, Thomas of Celano tells this story:

"The young birds [a brood of robins] became completely tame with the brothers [some Friars], and all ate together peacefully. But greed broke up this harmony, for a bigger one grew arrogant and harassed the smaller ones. When the big one had already eaten his fill, he still pushed the others away from the food. 'Look now', said the father, 'at what this greedy one is doing! He's full to bursting, but he's still jealous of his hungry brothers. He will die an evil death.' The punishment followed soon after the saint's word. The one who disturbed his brothers climbed on the edge of a water pitcher to take a drink, and suddenly fell into it and drowned; not a cat or any other animal was found that dared touch that one cursed by the saint" [7] (vol 2, p. 279)

Here, as in other similar episodes, animals' bad behaviour points to the violation of the "norm of necessity", the greedy desires for more than one needs. Moreover, the punishment is especially harsh and affects the animal bodies too, which become undesirable to anyone, humans and beasts alike. According to this "natural ethics", the violation of the natural order (to be found even in the food chain) implies the banishment from the cosmic fraternity. 
In this way, for Thomas of Celano, the very Franciscan fraternity is grounded upon such natural ethics and cannot be reduced to a code fixed by human arbitrary resolve [15].

Within this austere but engaging scenario, however, in Francis of Assisi's mind, sustainable consumption does not amount only to the useful and the essential ("necessitas"). Human integral sustainability also requires-quite paradoxically-unnecessary things, which the author of The Canticle of the Creatures grasps in the beauty of nature, shining all over Creation. Exactly for this reason, Thomas of Celano-always in The Remembrance of the Desire of a Soul - refers that Francis desired for him alone a portion of the garden with wild herbs and flowers: "He commands the gardener to leave the edges of the garden undisturbed, so that in their season the green of herbs and the beauty of flowers may proclaim the beautiful Father of all. He even orders that within the garden, a smaller garden should be set aside for aromatic and flowering herbs so that those who see them may recall the memory of eternal savour" [7] (vol. 2, p. 354).

This is a very relevant and insightful point. It must be so since it appears, at first sight, in sharp contrast with the radical prohibition of any private property, as stated in the Rule. Additionally, it is also incoherent with all the preceding monastic traditions, which admitted only the cultivation of edible or medicinal herbs. In elaborating the details of the "private garden with useless herbs", Thomas of Celano would have never transgressed or subverted the ban on private property without a hint to do so coming directly from The Canticle of the Creatures-where verse 9 mentions the "coloured flowers and herbs" ("coloriti fiori et herba"). Indeed, it is Francis himself, in the Canticle, who not only contravenes the monastic tradition but also breaks his own norm about poverty, the hinge of his religious choice [16]. He is even ready to alter the Biblical source, which he usually follows strictly. That "coloured flowers and herbs" included in verse 9 is the sign of the special attention to the beauty of creatures, conceived by God's imagination. Such aesthetical sensibility, in its turn, points up the superfluous as the peculiar trait of the human being.

\subsection{Francis of Assisi's Model in a Nutshell}

In this section, we have gathered three main points from Francis of Assisi's thought and life:

- The idea that nature unveils the basic ethics of consumption according to which any being can take from the environment all that is needed for its life ("necessitas") but no more;

- The idea that nature, through the variety of creatures it encompasses, can play a maieutic, pedagogical role for the human being;

- The idea that human life, in particular, implies a space for superfluous things where derogation from the strict "rule of necessity" can be accepted if it is done in view of the beauty of nature without disrupting the natural ethics unveiled by nature itself.

We will now see how these insights may converge with current developments in the life sciences.

\section{The Organism-Environment Relationships}

The field of evolutionary biology is currently experiencing a significant process of theoretical development. Many authoritative scholars in the field are working on elaborating, developing and testing a novel theoretical framework: the so-called Extended Evolutionary Synthesis (EES) [17-19]. The EES intends to overcome some perceived limitations of the mid-20th-century Neo-Darwinian or "Modern" Synthesis—nowadays also labelled as Standard Evolutionary Theory (SET). This causes lively debate between scholars advocating the novel synthesis and scholars claiming it is unnecessary [20]. The real challenge in this case-as in many other similar cases of theory change and paradigm shift in the history of science-has more to do with potential future developments than it has with current empirical adequacy [21].

We think that further development in EES may have very important implications for the issue of sustainability and also, specifically, for the human factor in sustainability 
itself. Indeed, the EES is relevant for the perspective undertaken in this paper for three main reasons:

1. EES contributes to sharpen our understanding of the decisive role the environment plays in shaping the life forms dwelling in it and to clarify that organisms modify the environment in ways that affect their own current traits and future evolution [22-25];

2. EES allows for insights in evolutionary biology to be applied to ecosystem science, and vice versa [26-28];

3. EES proposes interesting ways to incorporate studies on human cultural evolution within an extended biological-evolutionary framework [29-33].

In this section, we will mainly focus on Point 1 (and, in part, on Point 2); this will provide the biological ground for our proposal of a "pedagogical ecology". In the next section, we will address Point 3 (and, in part, Point 2 as well) and will show how the environment actually plays a pedagogical role in human culture and cultural evolution.

\subsection{Organisms Modify Their Environment}

The simple presence of organisms in an environment causes changes in the latter. On the basic level, this depends on organisms' physiological processes: trees affect the physical and chemical state of their surroundings; herbivores fertilize their pastures; fish affect water and reefs. However, things are subtler in this respect.

Organisms do not just affect their environment by way of by-products of their presence: they possess mechanisms that are apt to cause environmental changes. Beavers' ability to build dams and bring about extensive changes in freshwater basins provides a striking example. The widespread nesting ability of birds, mammals and insects is another eloquent case in point. A subtle example - which captured the attention of Charles Darwin himself [34] —is one of earthworms that modify their habitat to make it similar to an aquatic environment. This behaviour makes it possible for earthworms to keep having (during the past, possibly, more than 200 million years!) a physiology typical of aquatic organisms although they live on land [35].

The latter example also shows how the changes the organisms can cause on the environment have effects not just on their current condition and the way they manage to survive and reproduce but also - and most importantly —on their past and future "natural history". Earthworm behaviour prevented them from losing their aquatic physiology, and this, in turn, would affect their future evolution. The ability to modify the environment in ways that affect the future evolution by changing the selection pressures on the organisms that modify the environment, on their offspring and future generations, as well as, possibly, on organisms of other populations or species in that environment, has been called "niche construction" $[22,24,27,36,37]$. Niche construction theory is one of the pillars of the EES as it implies that "the organism influences its own evolution by being both the object of natural selection and the creator of the conditions of that selection" [38] (p. 106). Through niche construction, therefore, organisms often buffer environmental pressures on themselves and their progeny and also change selective pressures acting on the organisms of other species.

There are other three implications of niche construction theory that are momentous for our perspective in this paper [22]. First, the environmental aspect modified by the organism often lasts longer than the lifespan of the modifying organism, thus playing an evolutionary role beyond the organisms that bring it about and its "contemporaries" - this is the core of so-called "ecological inheritance" [36]. Secondly, the organism's trait (anatomical, physiological, behavioural, or whatever) that is directly responsible for the environmental change with niche-constructing import does not need to have a direct and strong genetic basis but can be (as it is often the case) an acquired/learned character or a character passed on from generation to generation via non-genetic channels (including social learning)-this is the main difference between the notion of niche construction and that of "extended phenotype" [39]. Thirdly, the consequences of organisms' niche-constructing activities do not need to constitute adaptations or be strictly related to organisms fitness-this 
is the contribution of niche construction theory against a strict "adaptationist" view of biological evolution [40].

In the light of these briefly sketched theoretical advances in the life sciences about the organisms' action in and on the environment, four points are worth stressing:

- Organisms often have traits that are apt to modify aspects of the environment actively and not just to react to environmental challenges;

- Organisms construct their niches, and in the process, the environment is not just a "punishing instance", selecting out unfit forms or presenting challenges to be faced, but also offers organisms chances to develop, stabilize, expand and perpetuate;

- Organisms' behaviour, through niche construction, influences the future course of development and evolution of their own population and of other populations dwelling in the same environment;

- The current view on evolutionary biology (namely, the EES with its niche-construction pillar) attributes a strong evolutionary causal role to the "real lives of concrete individual organisms" [23] - evolution is no longer only a matter of change in gene frequencies in the long run, but a process in which (a) the role of the individual organisms is not entirely reducible to their genetic make-up and (b) the role of the environment is not only that of selecting out organisms endowed with unfit genomes.

\subsection{The Environment Modifies the Organisms}

The role of the environment in modifying organisms is interestingly complementary to the role of organisms modifying the environment. In a sense, such a role of the environment in shaping organisms is acknowledged from the very onset of modern evolutionary biology, already with the 1809 Philosophical zoology by J. B. de Lamarck [41], according to which organisms change their morphology because of features of the environment relevant for their survival. It became more so with the 1859 C. R. Darwin's masterpiece On the origin of species [42], which brought in the theory of natural selection as a fundamental mechanism regulating the evolution of life forms on Earth. As we will see shortly (Section 3.2.1), natural selection can be regarded as the main way in which the environment changes organisms "downstream"-i.e., in the course of generations. However, recent developments in the life sciences have clearly shown that the environment also affects organisms to a significant extent during their development and ontogeny (the entire lifespan of an organism, from conception to death). This would count as an "upstream" effect of the environment upon organisms (as we will discuss in Section 3.2.2).

\subsubsection{Downstream Changes: Natural Selection}

Darwin's theory of evolution by natural selection still constitutes one of the core elements of the evolutionary view of life. In Darwin's time, natural selection soon appeared to be a strong hypothesis able to make many life phenomena understandable in a coherent and unitary framework.

The mechanism, in its most general understanding, works so. Organisms interact with their environment according to their traits. The specifics of the traits and those of the environment determine the level of adaptation and the fitness of the organism relative to the environment they live in-i.e., how well the organism copes with the challenges the environment poses to its survival and reproductive success. Fit organisms cope better with the environment and consequently have more chances to survive and reproduce. Unfit organisms survive worse and reproduce less, or not at all. Fit organisms will pass their traits to their offspring; unfit ones will fail to do so. In the long run, fitnessincreasing traits will spread across the population, whereas fitness-decreasing traits will tend to disappear. What is important to note is that absolutely fit (or unfit) traits or organisms do not exist as the degree of fitness is always relative to the specifics of the environment. Organisms with a high degree of fitness in a particular environment may well be significantly unfit in another. Additionally, the environment changes in time, often significantly and, sometimes, suddenly. 
Research in the last decades has provided extensive empirical evidence for natural selection. Moreover, it has been clarified that its effects may be-and often are-subtle and quite quick. It may have measurable effects in just a few generations. It may affect even the finest quantitative details of some trait. A suitable example for both points, extremely well documented, is the evolution of the beaks of Darwin's finches on Daphne Mayor, an island of the Galapagos Archipelagos. Peter and Rosemary Grant dedicated a great part of their scientific career to the study of the ecology and evolution of Darwin's finches in the Galapagos [43,44]. Between 1970 and 2000, they meticulously registered three parameters in Daphne Mayor: the amount of rainfall, the beak size of individuals of the finch species Geospiza fortis, and the availability of different kinds of seeds. Finches are granivorous-they feed on seeds. The size of the beaks is a key trait for finches as it is linked with the kinds of seeds finches consume. The amount of rain affects the proliferation of vegetation and consequently the availability of different kinds of seeds. In particular, on Daphne Mayor, periods of abundant rainfall make seeds with soft shells plentiful, whereas hard-shelled seeds are more available during periods of drought. Large-sized beaks, obviously, allow finches to feed more efficiently on hard-shelled seeds. The study showed that the mean beak size of $G$. fortis specimens increased measurably after just a few years of drought because of the scarcity of soft-shelled seeds and subsequently decreased again following years of abundant rainfall, when soft-shelled seeds became widespread.

This effect on finches' phenotype is clearly due to natural selection as finches with large-sized beaks can cope more effectively with a dry environment, survive better and reproduce more than specimens with small-sized beaks so that the large-beak trait spreads. The example beautifully shows how a change in a single environmental parameter (the amount of rainfall) can drive a change in organism morphology (the size of finches' beaks).

\subsubsection{Upstream Changes: Developmental and Phenotypic Plasticity}

Natural selection is not the only way through which the environment can determine changes in the constitution of organisms dwelling in it. Environmental parameters can also induce changes in organisms' morphology, anatomy, physiology, behaviour and cognition during the organisms' growth and development or as they learn new skills along their lifespan. The point can be eloquently illustrated by a few examples.

Effects of a single environmental parameter on the morphology and behaviour of fish have been studied in detail in three species: Bryconops caudomaculatus and Biotodoma wavrini in the Rio Cianurco basin (South-West Venezuela) [45], and Barbus neumayeri in the Mpanga river basin (West Uganda) [46]. These two basins are characterized by both zones where water flows in a continuous stream (in the river channel) and zones where water is stagnant (in the lagoon). Water behaviour also influences other parameters such as oxygen concentration and kinds of available food. The studies compared a number of traits-e.g., the body morphology, the shape of the mouth, the size of the gills and the feeding behaviour - of specimens of the three species taken from the flowing-water and the stagnant-water zones, respectively. The results showed that some of the traits (especially body shape and mouth morphology) differ appreciably between specimens from the river channel and specimens from the lagoon. In particular, body shape was more fusiform (and, thus, hydrodynamical) in specimens from the channels. The studies suggest that the phenotypic differences between specimens from the channel and specimens from the lagoon might be due, at least in part, to a direct effect of environmental parameters on phenotypic plasticity-i.e., the possibility of an organism's genotype to give rise to different phenotypes depending on environmental factors-and might not imply (or not depend only on) genetic differentiation among populations living in different habitats within the basin.

Other instances of environmental induction of novel phenotypes concern more behaviouralcognitive traits. Two instructive examples are provided by birds. The first one was studied in Scotland around 1950 and concerned specimens of blue tit (Cyanistes caeruleus) that had learned to open milk bottles (by beak-puncturing the bottles' foil caps) and feed on 
milk [47,48]. The observational study documented the learning of the new behaviour by the little birds as well as the spreading of this novel behaviour to conspecifics through copying. Tits obviously did not evolve to open milk bottles or to feed on milk. The motor behaviour used to open the bottles has been shown to be part of tits' motor repertoire, and the discovery of milk bottles as a food source may come from trial and error. However, the interesting point is that the novel behaviour has been likely induced in some "pioneer" by an environmental element (the presence of milk bottles on the thresholds of Scottish houses) and then spread across the population via social learning mechanisms. The second, more sophisticated case concerns ravens learning to use automobiles as nutcrackers [49]. This was studied in the city of Sendai, Japan, around the year 2000. Birds are known to crack nuts by throwing them on hard surfaces (including streets). Indeed, the suggestion of crows using cars as nutcrackers in Davis, California, in the 1970s has been refused by a formal study showing that nuts cracked by cars were just an accidental by-product of the throwing behavior [50]. However, in the Sendai case [49], ravens of the species Corvus corone have been actually and formally observed to use automobiles as nutcrackers. The behaviour occurs in zones with three shared features: (1) roads have intersections or sharp bends so that cars must stop or slow down; (2) Japanese walnut trees are present in the surroundings; (3) traffic has moderate intensity. Moreover, reconstruction of the "history" of the ravens" behaviour (by means of questionnaires) has shown that the first instances likely emerged in the vicinity of a driving school (where the three just mentioned environmental features are present and cars tend to move even more slowly). Additionally, ravens were observed to: (a) place a walnut beforehand at places where the car wheels were likely to pass over it, (b) put a walnut in front of a car stopped at a red traffic light, and (c) toss a walnut with the beak in front of slowly moving cars. Additionally, in this case, the behaviour cannot have a strong evolutionary or genetic basis and has been induced by specific features of the environment.

These two examples are striking cases of a more general tenet of the EES that stresses the role of the environment in causing the emergence of biologically relevant novelty that can directly (and often positively) affect organisms' fitness and indirectly influence populations' future evolution-this is the relevance EES attributes to the mechanisms of developmental plasticity and phenotypic accommodation [51-53]. The inducing effects of the environment can give rise to novel phenotypes without any involvement of genetic mutation, and such novel phenotypes often precede (and do not follow) genetic evolution.

\subsection{The Organism-Environment Complementarity}

In this section, we have briefly surveyed eloquent cases of peculiar organism-environment interactions. These were meant to highlight a general point at the core of the recent advances in evolutionary biology and the life sciences framed by the Extended Evolutionary Synthesis. Niche construction (Section 3.1) and environmental induction of novel phenotypes, along with developmental plasticity and phenotypic accommodation (Section 3.2.2), enrich the array of interactions between organisms and the environment that was mainly captured by the notion of natural selection upon genetic variants in the SET (Standard Evolutionary Theory).

These recent developments imply the acknowledgement of strong organism-environment complementarity $[17,54]$. According to this view:

- The selective environment is no longer independent of the organisms dwelling in it as the latter can actively modify the former through niche construction and buffer its selective features;

- The organisms are no longer independent from the environment, not just because the latter downstream affects the former, but also because environmental features can actively, and upstream, induce relevant biological novelty in the organisms.

The EES has enormous consequences on the way we understand the phenomenon of life and its evolution. For our perspective in this paper, we have stressed those implications that have direct links with the ecological discourse (i.e., with the study of the relationship between organisms and their environment) and that cannot be overlooked by any allegedly 
comprehensive approach to sustainability. What we still need to discuss is the application of these implications to the human organism specifically.

\section{Human-Environment Relationships: Culture and Pedagogy}

In this section, we will focus on the specifics of the relationships human beings and human populations entertain with the environment. The issue is huge and cannot evidently be exhausted here. However, we will focus on those aspects concerning organismenvironment complementarity in the human case. Human culture can be regarded as the general context where the human-environment relationships take place and develop. Interestingly, studies on human culture and cultural evolution have been enriched with some novel perspectives that, although not directly dependent upon or stemming from the mentioned developments in evolutionary biology, appear to follow a convergent path. Without focusing on the detailed recent history of these two fields of human knowledge (evolutionary biology and cultural evolution studies), we will begin by highlighting the reciprocal conceptual connections.

\subsection{The EES and Culture-Driven Human Evolution}

As we have seen, EES substantially alters the overall picture of biological evolution relative to SET. According to the latter, evolution proceeds, thanks to genetic changes that determine changes in the organisms' traits, including behavioural and cognitive ones; then, natural selection "filters" those modified traits, thus favouring the spread of those genetic endowments responsible for adaptive traits. This view has also been applied to human evolution and specifically to human cultural evolution. Here, the picture might be summarized as follows. Key cultural innovations-that is, innovations that are so momentous that they spawn an array of secondary products or behaviours [55], characterizing Homo evolution since about 2.5 million years ago, are mainly regarded as the eventual outcomes of genetic evolution. More precisely, the genetic endowment is seen as establishing anatomical and physiological traits (and specifically brain anatomy and physiology), which, in turn, are claimed to fix cognitive faculties; cultural behaviour is finally regarded as stemming from the cognitive faculties. By implication, this general view maintains that the emergence of key cultural innovations ultimately would require genetic change. Such reasoning has been applied to the emergence of complex cumulative culture exhibited by $H$. sapiens, claiming either that it depends on the genetic change bringing about the speciation event leading to our species 260,000 years ago [56-64] or that it stems from some key mutation that occurred about 50,000 years ago in some population of our species [65-69].

This picture, however, seems no longer tenable for at least two classes of reasons [33]. First, it nowadays appears in sharp contrast with the emerging view of evolution advocated by the EES and discussed above, and, second, because of a number of recent archaeological and paleo-anthropological data [33,70-76]. Indeed, the distribution in time and space of the innovations' appearance suggested by those data is inconsistent with a scenario attributing the spread of modern cultural traits to concomitant genetic evolutionary processes. No concomitant rise of innovations that one might associate with a sudden shift in human cognition produced by genetic change or speciation is observed at any given moment in the past in a particular region or population. No accumulation of innovations is observed in only one single region (what should be expected, instead, if a genetic change were the cause for them). Cultural innovations seem to appear, disappear, and reappear (with different specifics) at different times, in different places, and among different human fossil species across a huge geographical area encompassing Africa, the Near East, Europe and Asia. Such complex patterns of cultural innovation seem utterly incompatible with a scenario in which key cultural innovations would require associated and directly causally related genetic changes.

A quite different scenario can thus be proposed for the emergence of key cultural innovations and for cultural evolution more generally. This scenario proposes genuinely 
cultural mechanisms at the basis of cultural evolution that have been labelled as "cultural exaptation" and "cultural neural reuse" [33,70]. Cultural exaptation, in analogy with biological exaptation [77], suggests that novel cultural strategies may be devised by building upon existing strategies, either putting the latter at the service of new functions or combining them in novel ways in view of new tasks. Examples of cultural exaptation are:

- The use of ochre pigments. Compounds made with ochre are powerful photoprotective means that shield the skin from harmful ultraviolet radiation [78]. There is evidence suggesting the symbolic use of iron-rich pigments on personal ornaments since at least 80,000 years ago in Africa [79,80]. One can envision a scenario in which ochre was first exploited for its photoprotective function and, in a later phase, through cultural exaptation, becoming a means, for example, through body painting, to reinforce cultural mechanisms related to intra- and inter-group self-identification, leading to the emergence of diversified symbolic material cultures. A subsequent cultural exaptation may have occurred in an already fully symbolic context when ochre was purposely employed on ornaments and clothes [70];

- The invention of systems of notation (or "Artificial Memory Systems"-AMS), up to proper writing systems. There is a number of archaeological objects (dating from 72,000 to 14,000 years ago) that constitute Artificial Memory Systems in that the marks and incisions they bear stored information significant to our ancestors [70,71,81-83]. Production of such "notational" marks resorted to the motor and cognitive abilities previously developed for other tasks (from butchery activities on carcasses and preys to utilitarian modification of stone or bone tools to the production of abstract but nonnotational engravings) [71]. These abilities have been put at the service of notational function (i.e., the ability of the marks to point to, or stand for, objects or other meanings) and thus have been "culturally exapted". It can be argued that the invention of writing is a further step in the process where marks on objects (such as the incisions on clay tokes of the cuneiform writing system developed in Mesopotamia 5400 years ago) came to be associated not just with a meaning but also with the phonology of an existing spoken language [70].

The interesting point here is that the new cultural strategy emerging via cultural exaptation may back-affect the cognitive abilities of the groups introducing it. Symbolic use of ochre pigments likely affected aspects of social cognition. The invention of systems of notation affected numerical cognition [84-86]. The invention of writing systems affected the phonological processing of spoken language [87] and has had, in the course of the last few millennia, enormous impacts on human lifestyle [88,89], up to the emergence of theoretical culture as well as of modern science and technology.

Moreover, there are convincing data showing that new cultural strategies may have a direct impact on the neural substrates subserving them, contributing to create stable functional or anatomical brain networks specifically dedicated to those new strategies without involving any heritable genetic change. This holds true for writing systems [87,90-92] and systems of numerical notation [93,94], but likely also for much older cultural practices such as stone-tool-making [95]. This is the core idea of the notion of cultural neural reuse [96-98], also labelled as "neuronal recycling" [99] or "neural exploitation" [100].

This novel scenario for cultural evolution implies addressing an important issue. We have suggested that genetic mutation is not the source of relevant cultural novelty (and not even, at least entirely, of the cognitive and neural traits underlying it). Now, if there is no-or, at least, not necessarily-heritable genetic change at the basis of the emergence of cultural innovations, what ensures their transmission across generations? Our proposed answer to this question is two-faceted. On the one hand, the emergence of cultural novelties is accompanied by the excogitation of more and more subtle and dedicated transmission strategies and pedagogical means. Likely, the more so, the closer we are to the present. On the other hand, the environment, specifically the modifications caused in and on the environment by human populations, plays an essential role in the transmission process, thus progressively acquiring a more pedagogical role along human cultural evolution. 


\subsection{Cultural Transmission and Pedagogy}

The main and clearest examples of cultural evolution by cultural exaptation and cultural neural reuse mentioned in the previous subsection are literacy and arithmetic (i.e., symbolic treatment of exact quantity). Patently, acquiring such cultural abilities requires fine pedagogical means and enduring dedicated training. Humanity has developed the institution of schooling to this aim. With all likelihood, transmission strategies themselves evolve. The animal kingdom displays an array of different transmission strategies [101-103]; moreover, variation in transmission strategies does not seem to be entirely dependent on differences in the genetic endowment but rather to correlate with environmental and contextual features [104]. Explicit teaching, however, seems to be a characterizing feature of our species (at least among extant hominins), and this likely depends on the peculiarities of human cultural evolution up to exalted cumulative culture $[105,106]$. The relevance of transmission strategies, and their evolution, can also be ascertained on the archaeological level [107-109]; studies have also suggested the possibility that tool-making, transmission strategies, and language as an effective communication means have co-evolved and that more effective transmission strategies may also positively affect innovation. The evolutionary relevance of transmission strategies can also be inferred from experimental studies with non-human animals that can be trained in subtle motor or cognitive tasks outside their behavioural repertoire in the wild. Striking is the case of chimpanzees that acquired numerical abilities [110] or that of macaque monkeys that were trained to use a tool to reach for food and were also shown to undergo neural changes as a consequence of the training [111,112]. This suggests that an important way for hominins to support a sustained (and accelerating) pace of cultural evolution has been to "invest in pedagogy"-i.e., dedicating specific efforts in devising transmission strategies adequate to pass on cultural traits perceived as important in the group.

It is also worth mentioning (though this point cannot be deepened here) that many recent cultural innovations-from literacy to the fine arts or to smartphones and spacecrafts-do not seem to have an immediate survival value. After all, $H$. sapiens has managed quite well on this planet before the emergence of such cultural innovations. This, coupled with the considerations that (i) many cultural innovations take time to show their utility, even in terms of competitive advantages and not just as immediate survival means, and (ii) that investment in the transmission of cultural novelties is often necessary before their utility is unveiled, points out that the motivations beneath human cultural evolution might not always be in the search for utilitarian outcomes or payoff [113].

\subsection{Cultural Transmission and Environmental Heredity}

In Section 3.1, we touched upon the notion of ecological inheritance, stressing that the modifications organisms cause in the environment last longer than the lifespan of those organisms, thus being inherited by their progeny. The issue is broader in scope as the modified environment inherited by the progeny often plays a crucial role in the progeny's development, sometimes being also essential to ensure parent-offspring phenotypic similarity $[36,54,114]$, i.e., the fact that the offspring has traits similar to those of the parents may depend not just on the inherited genome but also, crucially, on the fact that the offspring grows and develops in the same environment of the parents, where the environment includes all the modifications caused by the parents themselves.

Now, culture-or, more precisely, the varied array of historically and geographically realized human cultures or traditions-has a momentous impact on the environment. Thus, the issue of ecological inheritance acquires a special relevance for the human being exactly because the human environment is always and thoroughly a cultural environment. Additionally, this point is further sharpened by the consideration of the key role pedagogy plays in human exalted cumulative culture (see Section 4.2).

Moreover, recent human history and prehistory have seen the rise of a number of institutions-from the "Oldowan carnivory institution" to agriculture or trade, cities or 
temples, up to public school systems and the United Nations. Recent research has just begun to address the topic of institutions in the light of the EES in evolutionary biology $[115,116]$.

Institutions are very old (the Oldowan is as old as 2.6 million years), but with the so-called Neolithic Revolution (e.g., [117]) — characterized by the domestication of plants and animals and the consequent development of stable settings and the possibility of accumulating goods - the urge to develop institutions increased progressively. Interestingly, from our standpoint, this parallels the increased capacity to modify the environment that domestication implies and brings with it $[116,118]$. Not by chance, among the proposals for the beginning of the Anthropocene [119]—i.e., the proposal to officially name the current geological epoch after the impact of human activities on planet Earth-there is the invention of domestication in the Neolithic Revolution [120].

It is worth stressing that, as far as the issue of institutions is concerned, a dimension of explicit long-term planning and of shared decision making [121] emerges as an additional character of human culture and, consequently, of the human-environment relationship. Even contemporary protocols to assess and mitigate the risk of degradation of specific environments tend to include human-related and institutional factors (such as policy for land use) besides physical, chemical and biological ones [122]. This, in turn, deepens the pedagogical role of the environment for the human being: as a matter of fact, any presentday human individual is born and grows in a highly institutionalized milieu. This further strengthens the link between the perspective undertaken in this paper and the issue of sustainability, which necessarily implies reflections on, and about, the level of institutions (from the local to the international ones).

\section{Conclusions: A Pedagogical Criterion for Ecology and Sustainable Development}

Francis of Assisi's model of sustainable human life (Section 2) helped us in stressing the pedagogical role the natural environment can play upon the human being. The following section (Section 3) discussed recent advancements in life sciences, culminating in the statement of a strong form of organism-environment complementarity. The environment influences the organisms as much as the organisms modify the environment, so the link is strong and strictly reciprocal. The previous section (Section 4) focused on the organismenvironment relationship in the human case. Here, culture assumes a crucial relevance. On the one hand, cultural evolution can be shown to dovetail with the more general picture of biological evolution advocated by the EES. On the other, cultural evolution finds some peculiarities: (a) in its heavy reliance on pedagogy, (b) in the fact that cultural strategies are not always developed in view of immediate utilitarian outcomes, and (c) in the effectiveness it has in modifying the environment (up to the point of creating institutions or inducing the Anthropocene).

Taken together, the relevance of pedagogy (Section 4.1) and the understanding of cultural transmission in terms of ecological inheritance, encompassing institutions (Section 4.2), suggest that the organism-environment relationship in the case of the human being is such that the human being constantly modifies the environment to the aim of modifying itself. Seen from this viewpoint, the pedagogical role of the environment on the human being shines through.

In this light, we propose a pedagogical criterion for ecology and sustainable development. This criterion implies that any modification imposed to the environment should also be assessed for its pedagogical import-i.e., for the consequences it has in the learning processes all human beings constantly undergo all life long, for the messages it passes to the people living in it, for the effects it will have on the future generations, and for the contexts it will create for all aspects of human life.

Though this might appear, at first sight, as a marginal aspect of the huge issue of the current ecological crisis and of the future sustainable development of humanity, looking at it from the viewpoint developed in what precedes may well unveil its strategic relevance and also (if the insights from Francis of Assisi are considered as well) its ethical and anthropological value. 
Author Contributions: Conceptualization, G.B. and I.C.; writing-original draft preparation, I.C. for Section 1, Section 3, Section 4, Section 5 and G.B. for Section 2; writing-review and editing, I.C. and G.B. All authors have read and agreed to the published version of the manuscript.

Funding: This research received no external funding.

Institutional Review Board Statement: Not applicable.

Informed Consent Statement: Not applicable.

Acknowledgments: The research presented here has been made possible, in part, by support from Etica SGR and 4.Manager to the Pontifical Antonianum University of Rome for its activities in the field of "Integral Ecology". We also thank two anonymous reviewers for their insightful comments, which also helped us to improve the manuscript.

Conflicts of Interest: The authors declare no conflict of interest. The sources of support mentioned in the Acknowledgment section had no role in the writing of the manuscript nor in the decision to publish it.

\section{References}

1. White, L. The historical roots of our ecological crisis. Science 1967, 155, 1203-1207. [CrossRef] [PubMed]

2. Lumbreras, S.; Oviedo, L.; Angel, H.-F. The missing piece in sustainability indices: Accounting for the human factor. Sustainability 2021, 13, 11796. [CrossRef]

3. John Paul II. Apostolical Letter Inter Sanctos. 29 December 1979. Available online: https://www.vatican.va/content/john-paulii/la/apost_letters/1979/documents/hf_jp-ii_apl_19791129_inter-sanctos.html (accessed on 23 January 2022).

4. Michetti, R. Francesco d'Assisi e il paradosso della minoritas: La Vita beati Francisci di Tommaso da Celano. In Nuovi Studi Storici; Istituto Storico per il Medioevo: Rome, Italy, 2004.

5. Dalarun, J. Gouverner c'est Servir. Essai de Démocratie Médiévale; Alma: Paris, France, 2021.

6. Dalarun, J. Sicut mater. Una rilettura del biglietto di Francesco d'Assisi a frate Leone. Frat. Fr. 2009, 75, 19-51.

7. Francis of Assisi. Early Documents; Armstrong, R.J., Wayne Hellman, J.A., Short, W., Eds.; New City Press: New York, NY, USA, 1999-2001; Volume 3.

8. Buffon, G. Il Cantico di frate Sole. Il soccorso delle creature all'uomo indegno di nominare il "Sommo Bene". Antonianum 2021, 96, 7-28.

9. Todeschini, G. Tavola rotonda. In Frater Franciscus. Atti del 48 Convegno Internazionale, Assisi 15-17 Ottobre 2020; Centro italiano di studi sull'Alto Medioevo: Spoleto, Italy, 2021; pp. 277-284, 316-324.

10. Marini, A. Sorores Alaudae. Francesco d'Assisi, il Creato e Gli Animali; Porziuncola: Assisi, Italy, 1989.

11. Marini, A. Francesco d'Assisi e il creato. In Umbria Terra Francescana; Maiarelli, A., Ed.; Porziuncola: Assisi, Italy, 2013; pp. 59-89.

12. Moretti, F. Dal Ludus Alla Laude, Giochi di Uomini, Santi e Animali Dall'alto Medioevo a Francesco d'Assisi; Edipuglia: Bari, Italy, 2007.

13. Frugoni, C. Uomini e Animali del Medioevo. Storie Fantastiche e Feroci; Il Mulino: Bologna, Italy, 2018.

14. Williams, C.D. Liberating the Enlightenment: How a transforms relationship with animals can transcend Modernity. Relig. Educ. 2003, 98, 95-107. [CrossRef]

15. Kiser, L.J. Animal Economies: The Lives of St. Francis in Their Medieval Contexts. Interdiscip. Stud. Lit. Environ. 2004, 11, 121-138. [CrossRef]

16. Kiser, L.J. The garden of St. Francis: Plants, landscape, and economy in thirteenth-century Italy. Environ. Hist. 2003, 8, 229-245. [CrossRef]

17. Laland, K.N.; Uller, T.; Feldman, M.W.; Sterelny, K.; Muller, G.B.; Moczek, A.; Jablonka, E.; Odling-Smee, J. The extended evolutionary synthesis: Its structure, assumptions and predictions. Proc. R. Soc. B 2015, 282, 20151019. [CrossRef]

18. Muller, G.B. Why an extended evolutionary synthesis is necessary. Interface Focus 2017, 7, 20170015. [CrossRef]

19. Pigliucci, M. An Extended Synthesis for Evolutionary Biology. Ann. N. Y. Acad. Sci. 2009, 1168, 218-228. [CrossRef]

20. Laland, K.; Uller, T.; Feldman, M.; Sterelny, K.; Müller, G.B.; Moczek, A.; Jablonka, E.; Odling-Smee, J.; Wray, G.A.; Hoekstra, H.E.; et al. Does evolutionary theory need a rethink? Nature 2014, 514, 161-164. [CrossRef] [PubMed]

21. Colagè, I. Prospective Fruitfulness as a Criterion for Theory-Change and Research-Strategy Option. Compr. Rev. Catalana Filos. 2014, 16, 61-86.

22. Laland, K.; Matthews, B.; Feldman, M.W. An introduction to niche construction theory. Ecol. Evol. 2016, 30, 191-202. [CrossRef] [PubMed]

23. Laland, K.N.; Sterelny, K.; Odling-Smee, F.J.; Hoppitt, W.; Uller, T. Cause and effect in biology revisited: Is Mayr's proximateultimate dichotomy still useful? Science 2011, 334, 1512-1516. [CrossRef]

24. Laland, K.N.; Odling-Smee, J.; Feldman, M.W. Evolution Evolutionary consequences of niche construction and their implications for ecology. Proc. Natl. Acad. Sci. USA 1999, 96, 10242-10247. [CrossRef]

25. Odling-Smee, F.J.; Erwin, D.; Palkovacs, E.; Feldman, M.; Laland, K.N. Niche construction theory: A practical guide for ecologists. Q. Rev. Biol. 2013, 88, 3-28. [CrossRef] 
26. Matthews, B.; Narwani, A.; Hausch, S.; Nonaka, E.; Peter, H.; Yamamichi, M.; Sullam, K.E.; Bird, K.C.; Thomas, M.K.; Hanley, T.C.; et al. Toward an integration of evolutionary biology and ecosystem science. Ecol. Lett. 2011, 14, 690-701. [CrossRef]

27. Matthews, B.; de Meester, L.; Jones, C.G.; Iberlings, B.W.; Bouma, T.J.; Nuutinen, V.; van der Koppel, J.; Odling-Smee, F.J. Under niche construction: An operational bridge between ecology, evolution, and ecosystem science. Ecol. Monogr. 2014, 84, 245-263. [CrossRef]

28. Meneganzin, A.; Pievani, T.; Caserini, S. Anthropogenic climate change as a monumental niche construction process: Background and philosophical aspects. Biol. Phil. 2020, 35, 38. [CrossRef]

29. Laland, K.N.; Odling-Smee, J.; Myles, S. How culture shaped the human genome: Bringing genetics and the human sciences together. Nat. Rev. Genet. 2010, 11, 137-149. [CrossRef]

30. Zeder, M.A. Why evolutionary biology needs anthropology: Evaluating core assumptions of the extended evolutionary synthesis. Evol. Anthr. Issues News Rev. 2018, 27, 267-284. [CrossRef] [PubMed]

31. D'Ambrosio, P.; Colagè, I. Extending epigenesis: From phenotypic plasticity to the bio-cultural feedback. Biol. Phil. 2017, 32, 705-728. [CrossRef]

32. Fuentes, A. The extended evolutionary synthesis, ethnography, and the human niche: Toward an integrated anthropology. Curr. Anthropol. 2016, 57, S13-S26. [CrossRef]

33. Colagè, I.; d'Errico, F. Culture: The driving force of human cognition. Top. Cogn. Sci. 2020, 12, 654-672. [CrossRef]

34. Darwin, C.R. The Formation of Vegetable Mould, through the Action of Worms, with Observations on Their Habits; John Murray: London, $\mathrm{UK}, 1881$.

35. Turner, J.S. The Extended Organism: The Physiology of Animal-Built Structures; Harvard University Press: Cambridge, MA, USA, 2000.

36. Odling-Smee, F.J. Niche constructing phenotypes. In The Role of Behavior in Evolution; Plotkin, X., Ed.; MIT Press: Cambridge, MA, USA, 1988

37. Odling-Smee, F.J.; Laland, K.N.; Feldman, M.W. Niche construction. Am. Nat. 1996, 147, 641-648. [CrossRef]

38. Levins, R.C.; Lewontin, R.C. The Dialectical Biologist; Harvard University Press: Cambridge, MA, USA, 1985.

39. Dawkins, R. The Extended Phenotype; Oxford University Press: Oxford, UK, 1982.

40. Gould, S.J.; Lewontin, R.C. The spandrels of San Marco and the Panglossian Paradigm: A critique of the adaptationist programme. Proc. R. Soc. Lond. Ser. B 1979, 205, 581-598.

41. Lamarck, J.B. Philosophie Zoologique; Musée d'Histoire Naturelle: Paris, France, 1809.

42. Darwin, C.R. On the Origin of Species by Means of Natural Selection; John Murray: London, UK, 1859.

43. Grant, P.R.; Grant, B.R. How and Why Species Multiply: The Radiation of Darwin's Finches; Princeton University Press: Princeton, NJ, USA, 2008.

44. Grant, R.P. Ecology and Evolution of Darwin's Finches; Princeton University Press: Princeton, NJ, USA, 1999.

45. Langerhans, R.B.; Layman, C.A.; Langerhans, A.K.; Dewitts, T.J. Habitat-associated morphological divergence in two Neotropical fish species. Biol. J. Linn. Soc. 2003, 80, 689-698. [CrossRef]

46. Langerhans, R.B.; Chapman, L.J.; Dewitts, T.J. Complex phenotype-environment associations revealed in an East African cyprinid. J. Evol. Biol. 2007, 20, 1171-1181. [CrossRef]

47. Fisher, J.; Hinde, R.A. The opening of milk-bottles by birds. Br. Birds 1949, 42, 347-357.

48. Hinde, R.A.; Fisher, J. Further observations of the opening of milk bottles by birds. Br. Birds 1951, 44, $393-396$.

49. Nihei, Y.; Higochi, H. When and where did crows learn to use automobiles as nutcrackers. Tohoku Psyhcologica Folia 2002, 60, 93-97.

50. Maple, T. Do crows use automobiles as nut-crackers? West. Birds 1974, 5, 97-98.

51. West-Eberhard, M.J. Developmental Plasticity and Evolution; Oxford University Press: Oxford, UK, 2003.

52. Price, T.D.; Qvarnstrom, A.; Irwin, D.E. The role of phenotypic plasticity in driving genetic evolution. Proc. R. Soc. Lond. B 2003, 270, 1433-1440. [CrossRef] [PubMed]

53. Moczek, A.P.; Sultan, S.; Foster, S.; Ledón-Rettig, C.; Dworkin, I.; Nijhout, H.F.; Abouheif, E.; Pfennig, D.W. The role of developmental plasticity in evolutionary innovation. Proc. R. Soc. B 2011, 278, 2705-2713. [CrossRef]

54. Odling-Smee, F.J.; Laland, K.N.; Feldman, M.W. Niche Construction: The Neglected Process in Evolution; Monographs in Population Biology, 37; Princeton University Press: Princeton, NJ, USA, 2003.

55. Reader, S.; Laland, K.N. Animal innovation: An introduction. In Animal Innovation; Reader, S., Laland, K.N., Eds.; Oxford University Press: Oxford, UK, 2003; pp. 1-9.

56. Bolhuis, J.J.; Tattersall, I.; Chomsky, N.; Berwick, R.C. How could language have evolved? PLoS Biol. 2014, 12, e1001934. [CrossRef]

57. Bruner, E. Functional craniology, human evolution, and anatomical constraints in the Neanderthal braincase. In Dynamics of Learning in Neanderthals and Modern Humans; Akazawa, T., Ogihara, N., Tanabe, H.C., Terashima, H., Eds.; Springer: Tokyo, Japan, 2014; Volume 2, pp. 121-129.

58. Coolidge, F.L.; Wynn, T. A cognitive and neuropsychological perspective on the Chatelperronian. J. Anthropol. Res. 2004, 60, 55-73. [CrossRef]

59. Coolidge, F.L.; Wynn, T. The working memory account of Neandertal cognition-How phonological storage capacity may be related to recursion and the pragmatics of modern speech. J. Hum. Evol. 2007, 52, 707-710. [CrossRef]

60. Coolidge, F.L.; Wynn, T. The Rise of Homo Sapiens: The Evolution of Modern Thinking; Oxford University Press: Oxford, UK, 2017.

61. Coolidge, F.L.; Wynn, T. The Rise of Homo Sapiens: The Evolution of Modern Thinking; Oxford University Press: Oxford, UK, 2018. 
62. McBrearty, S.; Brooks, A.S. The revolution that wasn't: A new interpretation of the origin of modern human behavior. J. Hum. Evol. 2000, 39, 453-563. [CrossRef]

63. Mithen, S.J. The Singing Neanderthals: The Origins of Music, Language, Mind and Body; Weidenfeld \& Nicolson: London, UK, 2005.

64. Shea, J. Homo sapiens is as homo sapiens was: Behavioral variability versus "Behavioral Modernity" in paleolithic archaeology. Curr. Anthropol. 2011, 52, 1-35. [CrossRef]

65. Bar-Yosef, O. On the nature of transitions: The middle to upper palaeolithic and the neolithic revolution. Camb. Archaeol. J. 1998, 8, 141-163. [CrossRef]

66. Klein, R.G. The Human Career; University of Chicago Press: Chicago, IL, USA, 1989.

67. Klein, R.G. Archeology and the evolution of human behavior. Evol. Anthropol. Issues News Rev. 2000, 9, 17-36. [CrossRef]

68. Tattersall, I. The Fossil Trail: How We Know What We Think We Know about Human Evolution; Oxford University Press: New York, NY, USA, 1995.

69. Mellars, P.A.; Stringer, C.B. (Eds.) The Human Revolution: Behavioral and Biological Perspectives on the Origins of Modern Humans; Edinburgh University Press: Edinburgh, UK, 1989.

70. D'Errico, F.; Colagè, I. Cultural exaptation and cultural neural reuse: A mechanism for the emergence of modern culture and behavior. Biol. Theory 2018, 13, 213-227. [CrossRef]

71. D’Errico, F.; Doyon, L.; Colagè, I.; Queffelec, A.; le Vraux, E.; Giacobini, G.; Vandermeersch, B.; Maureille, B. From number sense to number symbols. An archaeological perspective. Phil. Trans. R Soc. B 2017, 373, 20160518. [CrossRef] [PubMed]

72. D'Errico, F. The invisible frontier. A multiple species model for the origin of behavioral modernity. Evol. Anthropol. 2003, 12, 188-202. [CrossRef]

73. D'Errico, F.; Stringer, C.B. Evolution, revolution or saltation scenario for the emergence of modern cultures? Phil. Trans. R. Soc. Lond. B 2011, 366, 10601069. [CrossRef]

74. Villa, P.; Roebroek, W. Neandertal demise: An archaeological analysis of the modern human superiority complex. PLoS ONE 2014, 9, e96424. [CrossRef]

75. Pettitt, P. The Palaeolithic Origins of Human Burial; Routledge: New York, NY, USA, 2011.

76. Soressi, M.; McPherron, S.P.; Lenoir, M.; Dogandžić, T.; Goldberg, T.; Jacobs, Z.; Maigrot, T.; Martisius, N.L.; Miller, C.E.; Rendu, W.; et al. Neandertals made the first specialized bone tools in Europe. Proc. Natl. Acad. Sci. USA 2013, 110, 14186-14190. [CrossRef]

77. Gould, S.J.; Vrba, E.S. Exaptation-A missing term in the science of for. Paleobiology 1982, 8, 4-15. [CrossRef]

78. Rifkin, R.F.; Dayet, L.; Queffelec, A.; Summers, B.; Lategan, M.; d'Errico, F. Evaluating the photoprotective effects of ochre on human skin by in vivo SPF assessment: Implications for human evolution, adaptation and dispersal. PLoS ONE 2015, 10, e0136090. [CrossRef]

79. D’Errico, F.; Vanhaeren, M.; Barton, N.; Bouzouggar, A.; Mienis, H.; Richter, D.; Hublin, J.-J.; McPherron, S.P.; Lozoue, P. Additional evidence on the use of personal ornaments in the Middle Paleolithic of North Africa. Proc. Natl. Acad. Sci. USA 2009, 106, 16051-16056. [CrossRef]

80. D'Errico, F.; Backwell, L. Earliest evidence of personal ornaments associated with burial: The Conus shells from Border Cave. J. Hum. Evol. 2016, 93, 91-108. [CrossRef] [PubMed]

81. D'Errico, F. A new model and its implications for the origins of writing: The La Marche antler revisited. Camb. Archaeol. J. 1995, 5, 163-206. [CrossRef]

82. D'Errico, F. Palaeolithic origins of artificial memory systems: An evolutionary perspective. In Cognition and Material Culture: The Archaeology of Symbolic Storage; Renfrew, C., Scarre, C.C., Eds.; The McDonald Institute Monographs: Cambridge, MA, USA, 1998; pp. 19-50.

83. D'Errico, F. Memories out of mind: The archaeology of the oldest artificial memory systems. In The Mind's Eye: Multidisciplinary Approaches to The Evolution of Human Cognition, International Monographs in Prehistory, Ann Arbor; Nowell, A., Ed.; Berghahn Books: New York, NY, USA, 2002; pp. 33-49.

84. Bender, A.; Beller, S. Nature and culture of finger counting: Diversity and representational effects of an embodied cognitive tool. Cognition 2012, 124, 156-182. [CrossRef] [PubMed]

85. Beller, S.; Bender, A. The limits of counting: Numerical cognition between evolution and culture. Science 2008, 319, $213-215$. [CrossRef]

86. Bender, A.; Schlimm, D.; Beller, S. The cognitive advantages of counting specifically: A representational analysis of verbal numeration systems in Oceanic languages. Top. Cogn. Sci. 2015, 7, 552-569. [CrossRef]

87. Dehaene, S.; Cohen, L.; Morais, J.; Kolinsky, R. Illiterate to literate: Behavioural and cerebral changes induced by reading acquisition. Nat. Rev. Neurosci. 2015, 16, 234-244. [CrossRef]

88. Ong, W. Orality and Literacy: The Technologizing of the World; Routledge: New York, NY, USA, 2002.

89. Donald, M. Origins of the Modern Mind: Three Stages in the Evolution of Culture and Cognition; Harvard University Press: Cambridge, MA, USA, 1991.

90. Cohen, L.; Dehaene, S.; Naccache, L.; Lehéricy, S.; Dehaene-Lambertz, G.; Hénaff, M.-A.; Michel, F. The visual word form area: Spatial and temporal characterization of an initial stage of reading in normal subjects and posterior split-brain patients. Brain 2000, 123, 291-307. [CrossRef] 
91. Gaillard, R.; Naccache, L.; Pinel, P.; Clémenceau, S.; Volle, E.; Hasboun, D.; Dupont, S.; Baulac, M.; Dehaene, S.; Adam, C.; et al. Direct intracranial, fMRI, and lesion evidence for the causal role of left inferotemporal cortex in reading. Neuron 2006, 50, 191-204. [CrossRef]

92. Dehaene, S.; Pegado, F.; Braga, L.W.; Ventura, P.; Nunes Filho, G.; Jobert, A.; Dehaene-Lambertz, G.; Kolinsky, R.; Morais, J.; Cohen, L. How Learning to Read Changes the Cortical Networks for Vision and Language. Science 2012, 330, 1360-1364. [CrossRef]

93. Dehaene, S. The Number Sense (Revised); Oxford University Press: Oxford, UK, 2011.

94. Nieder, A.; Dehaene, S. Representation of Number in the Brain. Annu. Rev. Neurosci. 2009, 32, 185-208. [CrossRef]

95. Hecht, E.E.; Gutman, D.A.; Khreisheh, N.; Taylor, S.V.; Kilner, J.; Faisal, A.A.; Bradley, B.A.; Chaminade, T.; Stout, D. Acquisition of paleo- lithic toolmaking abilities involves structural remodeling to inferior frontoparietal regions. Brain Struct. Funct. 2014, 220, 2315-2331. [CrossRef] [PubMed]

96. Anderson, M.L. Neural reuse: A fundamental organizational principle of the brain. Behav. Brain Sci. 2010, 33, 245-313. [CrossRef] [PubMed]

97. Colagè, I. Human specificity: Recent neuro-scientific advances and new perspectives. ESSSAT News Rev. 2013, $23,5-19$.

98. Colagè, I.; D'Ambrosio, P. Exaptation and neural reuse: A research perspective into the human specificity. Antonianum 2014, 89, 333-358.

99. Dehaene, S.; Cohen, L. Cultural recycling of cortical maps. Neuron 2007, 56, 384-398. [CrossRef]

100. Gallese, V. Mirror neurons and the social nature of language: The neural exploitation hypothesis. Soc. Neurosci. 2008, 3, 317-333. [CrossRef]

101. Heyes, C.M. Social learning in animals: Categories and mechanisms. Biol. Rev. 1994, 69, 207-231. [CrossRef]

102. Hoppitt, W.; Laland, K.N. Social Learning: An Introduction to Mechanisms, Methods and Models; Princeton University Press: Princeton, NJ, USA, 2013.

103. Whiten, A. Cultural evolution in animals. Ann. Rev. Ecol. Evol. Syst. 2019, 50, 27-48. [CrossRef]

104. Coolen, I.; Bergen, Y.V.; Day, R.L.; Laland, K.N. Species difference in adaptive use of public information in sticklebacks. Proc. R. Soc. Lond. Ser. B 2003, 270, 2413-2419. [CrossRef]

105. Dean, L.G.; Kendal, R.L.; Schapiro, S.J.; Thierry, B.; Laland, K.N. Identification of the social and cognitive processes underlying human cumulative culture. Science 2012, 335, 1114-1118. [CrossRef]

106. Tennie, C.; Call, J.; Tomasello, M. Ratcheting up the ratchet: On the evolution of cumulative culture. Phil. Trans. R. Soc. B 2009, 364, 2405-2415. [CrossRef] [PubMed]

107. Heyes, C. Cognitive Gadgets: The Cultural Evolution of Thinking; Harvard University Press: Cambridge, MA, USA, 2018.

108. Morgan, T.J.H.; Uomini, N.T.; Rendell, L.E.; Chouinard-Thuly, L.; Street, S.E.; Lewis, H.M.; Cross, C.P.; Evans, C.; Kearney, R.; de la Torre, I.; et al. Experimental evidence for the co-evolution of hominin tool-making, teaching and language. Nat. Commun. 2015, 6, 6029. [CrossRef] [PubMed]

109. D'Errico, F.; Banks, W.E. The archaeology of teaching: A concep- tual framework. Camb. Archaeol. J. 2015, 25, 859-866. [CrossRef]

110. Matsuzawa, T. Symbolic representation of number in chimpanzees. Curr. Opin. Neurobiol. 2009, 19, 92-98. [CrossRef] [PubMed]

111. Ishibashi, H.; Hihara, S.; Takahashi, M.; Heike, T.; Yokota, T.; Iriki, A. Tool-use learning selectively induces expression of brain-derived neurotrophic factor, its receptor trkB, and neurotrophin 3 in the intraparietal multisensorycortex of monkeys. Cogn. Brain Res. 2002, 14, 3-9. [CrossRef]

112. Hihara, S.; Notoya, T.; Tanaka, M.; Ichinose, S.; Ojima, H.; Obayashi, S.; Fujii, N.; Iriki, A. Extension of corticocortical afferents into the anterior bank of the intraparietal sulcus by tool- use training in adult monkeys. Neuropsychologia 2006, 44, 2636-2646. [CrossRef] [PubMed]

113. Colagè, I. The human being shaping and transcending itself: Written language, brain, and culture. Zygon 2015, 50, 1002-1021. [CrossRef]

114. Badyaev, A.V.; Uller, T. Parental effects in ecology and evolution: Mechanisms, processes and implications. Phil. Trans. R. Soc. B 2009, 364, 1169-1177. [CrossRef]

115. Powers, S.T.; van Schaik, C.P.; Lehmann, L. How institutions shaped the last major evolutionary transition to large-scale human societies. Phil. Trans. R. Soc. B 2016, 371, 20150098. [CrossRef]

116. Davison, D.R.; Andersson, C.; Michod, R.E.; Kuhn, S.L. Did human culture emerge in a cultural evolutionary transition in individuality? Biol. Theory 2021, 16, 213-226. [CrossRef]

117. Barker, G. The Agricultural Revolution in Prehistory: Why Did Foragers Become Farmers? Oxford University Press: Oxford, UK, 2009.

118. Zeder, M.A. Domestication as a model system for the extended evolutionary synthesis. Interface Focus 2017, 7, 20160133. [CrossRef]

119. Crutzen, P.J.; Stoermer, E.F. The "Anthropocene". Glob. Sci. Newsl. 2000, 41, 17-18.

120. Lewis, S.L.; Maslin, M.A. Defining the Anthropocene. Nature 2015, 519, 171-178. [CrossRef]

121. Tomasello, M.; Carpenter, M. Shared intentionality. Dev. Sci. 2007, 10, 121-125. [CrossRef] [PubMed]

122. Duro, A.; Piccione, V.; Ragusa, M.A.; Veneziano, V. New Environmentally Sensitive Patch Index-ESPI for MEDALUS protocol. AIP Conf. Proc. 2014, 1637, 305-312. [CrossRef] 